\title{
Pengaruh Penggunaan Media Pembelajaran (E-Learning) dan Motivasi Terhadap Prestasi Belajar Bagi Mahasiswa S1 Akuntansi FE Universitas Semarang
}

${ }^{1}$ Asah Wiari Sidiq, ${ }^{2}$ Muryanto Agus Nuswantoro,

${ }^{1}$ S1 Manajemen FE, Universitas Semarang

${ }^{1}$ S1 Manajemen FE, Universitas Semarang

\section{INFO ARTIKEI}

\section{Proses Artikel}

Dikirim :

Diterima:

Dipublikasikan: April 2021

\begin{abstract}
ABSTRAK
Covid-19 mengakibatkan kebijakan Work From Home (WFH) termasuk dunia pendidikan. Penggunaan media pembelajaran (elearning) adalah proses belajar mengajar dengan menggunakan peralatan elektronika dengan cara menciptakan dan mengembangkan metode jarak jauh dengan tujuan pendistribusian materi untuk memudahkan dalam pembelajaran. Tujuan menggunakan media pembelajaran elektronik (E-Learning) akan memberikan dampak dalam memotivasi belajar untuk berprestasi.
\end{abstract}

Analisis yang digunakan untuk menguji validitas, reliabilitas serta regresi berganda menggunakan SPSS dengan data primer yang berasal dari kuesioner mahasiswa S1 Akuntansi FE Universitas Semarang dengan sampel sebanyak 85 mahasiswa.

Penelitian ini menyatakan ada pengaruh yang positif dari media pembelajaran (elearning) terhadap prestasi belajar mahasiswa dengan nilai signifikan $<5 \%$, motivasi berpengaruh positif terhadap prestasi belajar namun tidak signifikan. Sedangkan media pembelajaran (elearning) dan motivasi berpengaruh yang positif terhadap prestasi belajar dengan kontribusi nilai $68,3 \%$ dan $32,7 \%$ selebihnya dipengaruhi indikator lain yang tidak dimasukan didalam penelitian.

Kata Kunci :

Pembelajaran, media pembelajaran, motivasi 


\section{PENDAHULUAN}

Meluasnya wabah corona di Indonesia pada awal tahun sampai saat ini tidak hanya masalah kesehatan, tetapi menimbulkan dampak yang sangat signifikan di berbagai bidang termasuk pendidikan. Wabah ini membuat semua aktifitas terhenti dan terpusat hanya pada satu tempat atau rumah yang dihuni. Berbagai kegiatan dalam memutus rantai virus covid, pemerintah mengeluarkan kebijakan dengan menghimbau masyarakat untuk melakukan physical distancing, selalu menjaga jarak aman, menjauhi kerumunan, perkumpulan atau segala aktifitas yang mengundang banyak orang serta menghindari berbagai bentuk pertemuan yang melibatkan orang banyak. Upaya-upaya tersebut yang bisa digunakan agar covid-19 tidak menyebar bahkan dapat memutus mata rantai penyebaran yang saat ini terjadi. Hal ini mengakibatkan penurunan aktifitas masyarakat keluar rumah.

Kebijakan lain yang ditempuh pemerintah agar roda kehidupan tetap berjalan diterapkan kebijakan Work From Home (WFH) dengan tujuan segala pekerjaan dapat diselesaikan di rumah termasuk belajar di rumah. Adanya pandemi mengharuskan dunia pendidikan dan proses belajar mengajar di rumah dengan menggunakan media pembelajaran elektronik atau elearning. Dengan pembelajaran jarak jauh atau PLJJ, dosen dan mahasiswa dapat memanfaatkan kemajuan teknologi secara maksimal dan efektif.

Menurut Karwati (2014), E-learning merupakan proses belajar mengajar dengan menggunakan perangkat elektronika seperti komputer dalam memperoleh materi belajar sesuai dengan kebutuhan dan keinginannya. Penggunaan media pembelajaran (E-Learning) merupakan aktifitas atau proses belajar mengajar dengan menggunakan komputer atau peralatan elektronika lainnya dalam penciptaan kreatifitas dan inovasi. Disamping itu dapat membantu dalam perkembangan dan penyampaian materi dan memudahkan berinteraksi dan berkomunikasi dalam proses belajar mengajar di tempat manapun berada tanpa terhalang oleh waktu. Rahmanisa (2014) mengungkapkan dengan menggunakan Media pembelajaran (E-Learning), mahasiswa dapat menyerap dan mendapatkan berbagai materi atau bahan yang diajarkan, mendorong untuk berperan aktif dan meningkatkan kemadirian dalam belajar, serta meningkatkan mutu materi dan bahan dari proses pembelajaran. Mahasiswa lebih bisa disiplin waktu. Penggunaan Media Pembelajaran (E-Learning) memberikan banyak manfaat bagi pengajar dalam memberikan bahan dan materi perkuliahan maupun mahasiswa sebagai penerima materi.

Penggunaan media pembelajaran (E-Learning) dapat memberikan metode dan strategi dalam memfasilitasi proses belajar mengajar bagi dosen dan mahasiswa, baik individu maupun kelompok sehingga meningkatkan kemampuan personal dalam mewujudkan kemandirian belajar dan peningkatan ketrampilan sosial. Selain itu penggunaan media pembelajaran (E-Learning) memiliki fungsi yang berbeda dalam implementasinya, seperti sarana dan prasarana yang digunakan dalam pembelajaran, karakteristik materi maupun karakteristik pengajar tergantung dari kebijakan yang telah disepakat.

Emda (2017) mendefinisikan motivasi belajar adalah dorongan seorang untuk melakukan suatu guna mencapai tujuan. Sedangkan menurut Manuhutu (2015), motivasi belajar adalah semua daya penggerak siswa yang mendorong untuk belajar serta menjamin keberlangsungan, memberikan arah kegiatan belajar, sehingga dari penelitian terebut disimpulkan bahwa motivasi belajar adalah dorongan atau usaha dalam diri setiap individu 
atau sesorang dalam mencapai tujuan atau cita-cita. Orang yang menyukai penggunaan media pembelajaran (E-Learning) akan meningkatkan motivasi untuk berprestasi namun sebaliknya akan memberikan penurunan terhadap motivasi untuk belajar bagi mahasiswa yang tidak menyukai penggunaan media pembelajaran (E-Learning).

Syafii, Marfiyanto, \& Rondiyah, (2018) yang mendefinisikan prestasi belajar merupakan pencapaian hasil pembelajaran setelah terlaksananya proses kegiatan belajar mengajar yang dapat meningkatkan prestasi belajar yang dinyatakan dalam bentuki nilai yang diperoleh dari seorang pengajar dari berbagi mata pelajaran dan bidang studi yang telah dipelajari oleh siswa atau mahasiswa. Kesimpulan dari penelitian tersebut, menyatakan bahwa prestasi belajar merupakan hasil penilaian akhir dari usaha belajar siswa atau mahasiswa selama proses belajar dan pelaksanaan ujian akhir mendapatkan hasil yang baik berupa angka atau huruf.

Pemanfaatan teknologi elektronik, seperti perangkat komputer dan jaringan internet sangat diperlukan dalam pelaksanaan pembelajaran online. Para mahasiswa dapat memperoleh bahan-bahan pembelajaran melalui E Libraryatau atau perpustakaan elektronik dan e-book atau sering disebut buku elektronik dalam memperoleh koleksi materi yang ada di perpustakaan berupa jurnal atau artikel, majalah, buku, atau surat kabar. Kehadiran jaringan internet sangat mendominasi dilakukannya pembelajaran jarak jauh karena belajar bisa dilakukan dimanapun tanpa terikat oleh ruang dan waktu.

Tujuan penelitian untuk mengetahui pengaruh penggunaan media pembelajaran (ELearning) terhadap prestasi belajar mahasiswa, pengaruh motivasi belajar terhadap prestasi belajar mahasiswa dan pengaruh dari penggunaan media pembelajaran (ELearning) dan motivasi belajar terhadap prestasi belajar mahasiswa

\section{KAJIAN PUSTAKA}

\section{Media Pembelajaran (E-Learning)}

Penggunaan media pembelajaran (E-Learning) adalah kegiatan belajar mengajar dengan bantuan perangkat elektronika dan jaringan internet. Dalam pelaksanaannya, media pembelajaran dapat menggunakan handphone, komputer, laptop atau perangkat elektronik lainnya serta metode yang digunakan dapat berupa audio, video (zoom, clasroom) atau kombinasi dari berbagai metode.

Menurut Jaya Kumar C. Koran 2002 dalam (Elyas, 2018), E-Learning adalah proses pengajaran dan pembelajaran dengan menggunakan rangkaian peralatan elektronika seperti LAN, WAN, atau Internet dalam penyampaian materi belajar, melakukan berbagi cara untuk berkomunisi, berinteraksi dan bimbingan kepada siswa atau mahasiswa. Definisi lainnya mengenai media pembelajaran adalah pembelajaran atau proses belajar mengajar jarak jauh dengan menggunakan perangkat elektronik dan internet.

Pelaksanaan penggunaan media pembelajaran (E-Learning) tidak hanya di distribusikan melalui on-line saja tetapi dapat melalui penyebaran CD/DVD atau melalui jaringan lokal yang dijalankan secara on-line dan real-time ataupun secara off-line atau archieved. Pendistribusian dan penggunaan materi yang disebarkan melalui CD/DVD sudah termasuk metode pembelajaran, selanjutnya siswa atau mahasiswa dapat memanfaatkantode tersebut untuk belajar dan menimba ilmu di tempat manapun. 
Penggunaan media pembelajaran (E-learning) merupakan proses belajar mengajar jarak jauh yang sangat membantu dan memudahkan mentransfer ilmu walaupun dari berbagai tempat atau ruang yang tidak sama, namun dalam pelaksanaan pembelajaran melalui jarak jauh mempunyai kelebihan dan kelemahan tergantung bagaimana penggunaan media pembelajaran (e-learning) tersebut.

\section{Motivasi Belajar}

Aurora \& Effendi, (2019) mendefiniskan motivasi belajar sebagai sebuah dorongan dalam diri yang mampu meningkatkan minat dalam melakukan sesuatu, sehingga akan terdorong seseorang melakukan sebuah pekerjaan dengan baik Menurut Donald dan Oemar dalam (2019) dan Emda (2017) dikatakan juga bahwa motivasi merupakan keadaan dalam diri sesorang untuk melakukan perubahan akibat timbulnya perasaan dan reaksi dalam mencapai tujuan yang diinginkan.

Yadewani \& Bayu (2016) membagi tiga fungsi motivasi, sebagai berikut

1. Mendorong berbuat, jadi dapat dikatakan sebagai motor penggerak dalam melepaskan energi.

2. Menentukan pedoman dalam melakukan perbuatan terhadap apa yang akan dicapai.

3. Melakukan pemilihan dan penyeleksian perbuatan yang akan dikerjakan dalam mencapai tujuan dengan meninggalkan perbuatan yang tidak bermanfaat.

\section{Prestasi Belajar}

Prestasi Belajar merupakan hasil dari kegiatan yang telah dilakukan dan diciptakan oleh individu maupun kelompok. Sebalikan seseorang yang tidak melakukan kegiatan tidak akan mencapi prestasi. Dalam pencapaian prestasi tidak semudah orang mengatakan, harus ada pengorbanan dan perjuangan yang harus dihadapi untuk mencapainya. Hanya dengan keuletan dan optiminisme diri yang dapat membantu mencapainya. Untuk itu wajar dalam mencapai suatu prestasi dibutuhkan kerja keras dan keuletan dalam belajar. Sedangkan belajar adalah suatu aktivitas yang dilakukan secara sadar untuk memperoleh sejumlah ilmu dari bahan yang telah dipelajari. Belajar adalah suatu perubahan, perubahan dalam arti menuju ke perkembangan pribadi seutuhnya.

Rusmiati (2017) dan Yadewani \& Bayu (2016) menyatakan prestasi belajar adalah cerminan dari suatu proses pembelajaran, hasil dari suatu usaha dan interaksi berbagai faktor yang mempengaruhi baik dari dalam maupun luar individu yang dilakukan seseorang. Kesimpulan dari pengertian tersebut bahwa prestasi belajar merupakan hasil dari pembelajaran yang dilakukan siswa atau mahasiswa dalam menyelesaikan proses pembelajaraan. 


\section{Kerangka Pemikiran Teoritis}

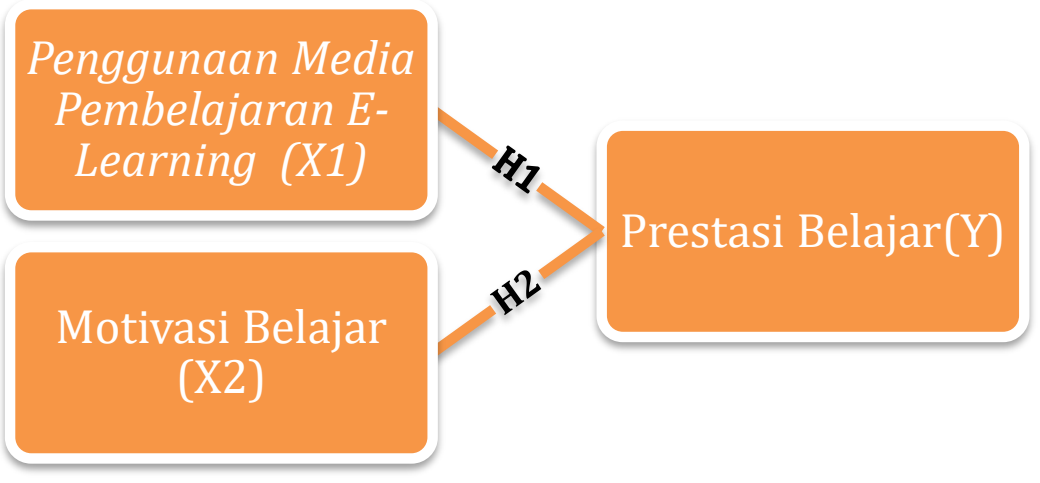

Sumber : Penelitian Terdahulu

H1 :Penggunaan Media E- Learning Berpengaruh Terhadap Prestasi Belajar

H2 :Motivasi Belajar berpengaruh Terhadap Prestasi Belajar

\section{METODE PENELITIAN}

Metodologi penelitian yang digunakan adalah kuantitatif dengan analisis uji validitas, reliabitas, asumsi klasik dan analisis regresi linear berganda dan uji hipotesis seperti uji t, uji F dan uji determinasi.

Penelitian ini menggunakan populasi dari mahasiswa aktif yang mengisi KRS pada semester gasal tahun 2020/2021 S1 Akuntasi kelas sore Fakultas Ekonomi Universitas Semarang dengan jumlah 610 mahasiswa. Sedangkan penggunaan sampel dalam penelitian sejumlah 85 mahasiswa.

HASIL DAN PEMBAHASAN

Data responden dari penelitian yang digunakan, yaitu sebagai berikut :

\begin{tabular}{|c|c|c|c|}
\hline \multicolumn{2}{|c|}{ Tabel 1 Tabel Data Responden } \\
\hline \multirow{2}{*}{ Karakteristik } & Kategori & $\begin{array}{c}\text { Jumlah } \\
\text { responden }\end{array}$ & $\%$ \\
\hline \multirow{2}{*}{ Jenis Kelamin } & Laki-laki & 38 & 45 \\
\cline { 2 - 4 } & Perempuan & 47 & 55 \\
\hline \multirow{2}{*}{ Usia } & $20-21$ & 30 & 35 \\
\cline { 2 - 4 } & $22-23$ & 28 & 33 \\
\cline { 2 - 4 } & $24-25$ & 27 & 32 \\
\hline
\end{tabular}

Sumber : Data diolah, 2020 


\section{Analisis Data}

\section{Pengujian Validitas}

Hasil pengujian validasi menyatakan semua indikator data kuesioner valid yaitu memiliki nilai korelasi $r>0,30$, nilai korelasi penelitian lebih besar dari 0,30 , sehingga layak untuk dijadikan instrumen dalam penelitian.

\section{Hasil Uji Reliabilitas}

Uji reliablitas digunakan untuk mendapatkan data yang reliabel. Uji reliabilitas dalam penelitian ini menggunakan rumus alpha. Apabila variabel yang diteliti mempunyai cronbach's alpha $>60 \%(0,06)$ maka variabel tersebut reliabel, sebaliknya cornbach's alpha $<60 \%(0,06)$ maka variabel tersebut tidak reliabel. Pengolahan data menggunakan program SPSS versi 21 yang hasilnya disajikan sebagai berikut :

Tabel 2 tabel Hasil Uji Reliabilitas

\begin{tabular}{|c|c|c|}
\hline Variabel & $\begin{array}{c}\text { Cronbach's } \\
\text { Alpha }\end{array}$ & Keterangan \\
\hline $\mathrm{X} 1$ & 0,851 & Reliabel \\
\hline $\mathrm{X} 2$ & 0,702 & Reliabel \\
\hline $\mathrm{Y}$ & 0,795 & Reliabel \\
\hline
\end{tabular}

Sumber : Data diolah, 2020

\section{Hasil uji Normalitas}

Tabel 3 Tabel Uji Kolmogrov-Smirnov Test

One-Sample Kolmogorov-Smirnov Test

\begin{tabular}{|c|c|c|}
\hline & & $\begin{array}{l}\text { Unstandardized } \\
\text { Residual }\end{array}$ \\
\hline \multicolumn{2}{|c|}{$\overline{\mathrm{N}}$} & 85 \\
\hline & Mean &, 0000000 \\
\hline Normal Parameters ${ }^{\mathrm{a}, \mathrm{o}}$ & Std. Deviation & 2,92525557 \\
\hline \multirow{3}{*}{ Most Extreme Differences } & Absolute & 075 \\
\hline & Positive & 075 \\
\hline & Negative &,- 047 \\
\hline \multicolumn{2}{|c|}{ Kolmogorov-Smirnov Z } & 690 \\
\hline \multicolumn{2}{|c|}{ Asymp. Sig. (2-tailed) } & ,728 \\
\hline
\end{tabular}

a. Test distribution is Normal.

b. Calculated from data.

Sumber: Data diolah, 2020

Dari diatas, dapat disimpulkan bahwa nilai signifikasi Kolmogrov-Smirnov lebih besar dari alpha yaitu 0,728 $>0,05$ maka data dinyatakan terdistribusi normal. 


\section{Uji Multikoloniaritas}

Tabel 4 Tabel Multikolinieritas

\section{Coefficients $^{\mathrm{a}}$}

\begin{tabular}{|c|c|c|c|c|c|c|c|}
\hline \multirow[t]{2}{*}{ Model } & \multicolumn{2}{|c|}{$\begin{array}{l}\text { Unstandardized } \\
\text { Coefficients }\end{array}$} & $\begin{array}{l}\text { Standardized } \\
\text { Coefficients }\end{array}$ & \multirow[t]{2}{*}{$\mathrm{T}$} & \multirow[t]{2}{*}{ Sig. } & \multicolumn{2}{|c|}{$\begin{array}{l}\text { Collinearity } \\
\text { Statistics }\end{array}$} \\
\hline & B & $\begin{array}{l}\text { Std. } \\
\text { Error }\end{array}$ & Beta & & & Tolerance & VIF \\
\hline (Constant) & 15,250 & 4,944 & & 3,084 & ,003 & & \\
\hline $\begin{array}{c}\text { Media Pembelajaran } \\
\text { (E-learning) }\end{array}$ & 632 & ,047 & ,831 & 13,519 & , 000 & ,999 & 1,001 \\
\hline Motivasi Belajar & ,073 & ,217 &, 021 & ,335 & ,739 & ,999 & 1,001 \\
\hline
\end{tabular}

a. Dependent Variable: Prestasi Belajar

Dari hasil perhitungan yang ada pada data diatas menunjukkan variabel bebas dengan tingkat VIF sama dengan 1 dan nilai tersebut kurang dari 10 sehingga kesimpulan dari analisa adalah bebas dari Multikolinieritas.

\section{Uji Heteroskedastisitas}

Tabel 5 Tabel Hasil Uji Glejser Coefficients $^{\mathrm{a}}$

\begin{tabular}{|c|r|r|r|r|r|}
\hline \multirow{2}{*}{ Model } & \multicolumn{2}{|c|}{$\begin{array}{c}\text { Unstandardized } \\
\text { Coefficients }\end{array}$} & $\begin{array}{c}\text { Standardized } \\
\text { Coefficients }\end{array}$ & \multirow{2}{*}{ Sig. } \\
\cline { 2 - 4 } & \multicolumn{1}{|c|}{ B } & Std. Error & \multicolumn{1}{|c|}{ Beta } & & \\
\hline (Constant) & 3,931 & 3,119 & & 1,260 &, 211 \\
Media Pembelajaran &,- 002 &, 029 &,- 007 &,- 063 &, 950 \\
( E-learning) X1 & & & & & \\
Motivasi Belajar X2 &,- 138 &, 137 &,- 111 & $-1,012$ &, 314 \\
\hline
\end{tabular}

Sumber : data diolah, 2020

Berdasarkan data tersebut menunjukkan bahwa tidak ada satupun variabel bebas yang signifikan secara statistik mempengaruhi variabel terikat absolut (abs). Hal ini terlihat probabilitas signifikannya diatas $5 \%$ yaitu pada tabel 5 dimana variabel media pembelajaran (e-learning) pada signifikasi 0,950 dan variabel motivasi belajar pada signifikan 0,314. sehingga semua variabel berada pada nilai signifikasi $>0,05$ maka kesimpulan dari model regresi dinyatakan bahwa tidak mengandung adanya Heteroskedastisitas. 


\section{Regresi Linier Berganda}

\section{Tabel 6 Tabel Hasil Uji Regresi Linier Berganda Coefficients}

\begin{tabular}{|c|c|c|c|c|c|}
\hline \multirow[t]{2}{*}{ Model } & \multicolumn{2}{|c|}{$\begin{array}{l}\text { Unstandardized } \\
\text { Coefficients }\end{array}$} & \multirow{2}{*}{$\begin{array}{c}\text { Standardized } \\
\text { Coefficients }\end{array}$} & \multirow[t]{2}{*}{$\mathrm{t}$} & \multirow[t]{2}{*}{ Sig. } \\
\hline & B & Std. Error & & & \\
\hline (Constant) & 15,250 & 4,944 & & 3,084 & ,003 \\
\hline $1 \begin{array}{c}\text { Media Pembelajaran( } \\
\text { E-learning) X1 }\end{array}$ & ,632 &, 047 & ,831 & 13,519 & ,000 \\
\hline Motivasi Belajar X2 & 073 & ,217 & ,021 &, 335 & ,739 \\
\hline
\end{tabular}

Sumber : data diolah, 2020

Hasil persamaan regresi linier berganda diatas, memberikan pengertian bahwa Media Pembelajaran (E-learning) (X1), Motivasi Belajar (X2), berpengaruh positif terhadap Prestasi Belajar (Y).

1. Koefisien regresi untuk variabel Media Pembelajaran (E-learning) (b1) sebesar 0,831 yang bertanda positif $(+)$, hal ini menunjukkan bahwa apabila mahasiswa memahami dan mampu mengaplikasikan media pembelajaran (e-learning) dengan baik, maka mahasiswa akan menjadi giat dalam belajar

2. Koefisien regresi untuk variabel motivasi belajar (b2) dengan nilai 0,21 yang bertanda positif $(+)$, menunjukkan bahwa apabila motivasi belajar semakin menarik, maka mahasiswa akan semakin berprestasi. Kesimpulan dari persamaan regresi dia atas dinyatakan bahwa variabel Media Pembelajaran (E-learning) (X1) dan variabel Motivasi Belajar (X2) mempunyai pengaruh positif terhadap prestasi belajar (Y). Dan faktor dominan yang paling mempengaruhi prestasi belajar adalah Media Pembelajaran (E-learning) yang ditunjukkan dengan koefisien regresi paling besar dibandingkan dengan variabel motivasi belajar yaitu 0,831 .

\section{Uji Signifikasi (t)}

Tabel 7 Tabel Hasil Uji t

Coefficients $^{\mathrm{a}}$

\begin{tabular}{|c|c|c|c|}
\hline \multirow[b]{2}{*}{ Model } & $\begin{array}{c}\text { Standardized } \\
\text { Coefficients } \\
\end{array}$ & \multirow[b]{2}{*}{$\mathrm{T}$} & \\
\hline & Beta & & \\
\hline $1 \quad$ (Constant) & & 3,084 & ,003 \\
\hline Media Pembelajaran (E-learning) X1 &, 831 & 13,519 & ,000 \\
\hline Motivasi Belajar X2 &, 021 & ,335 &, 739 \\
\hline
\end{tabular}

a. Dependent Variable : Prestasi Belajar Y

Sumber : data diolah, 2020 
Hasil analisa dan pengujian secara individu atau parsial terhadap variabel :

1. Pengaruh Media Pembelajaran (elearning) terhadap prestasi belajar Pengujian hipotesa mengenai pengaruh variabel media pembelajaran (elearning) terhadap prestasi belajar ditunjukkan dengan nilai t sebesar 13,519 dengan nilai signifikansi $<0,05$. Artinya ada pengaruh positif media pembelajaran (elearning) terhadap prestasi belajar dengan tingkat signifikansi $<5 \%$.

2. Pengaruh Motivasi terhadap prestasi belajar Pengujian hipotesa mengenai pengaruh variabel motivasi terhadap prestasi belajar menunjukkan nilai t sebesar 0,335 dengan nilai signifikansi sebesar $>0,05$. Artinya motivasi berpengaruh positif motivasi terhadap prestasi belajar namun tidak signifikan.

\section{Uji F (Simultan)}

Tabel 8 Tabel Hasil Uji F

ANOVA $^{\mathrm{a}}$

\begin{tabular}{|c|r|r|r|r|l|}
\hline Model & \multicolumn{1}{|c|}{ Sum of } & Df & Mean Square & F & Sig. \\
\hline Squares & & & & \\
\hline Regression & 1602,190 & 2 & 801,095 & 91,388 &, $000^{\mathrm{b}}$ \\
Residual & 718,798 & 82 & 8,766 & & \\
Total & 2320,988 & 84 & & & \\
\hline
\end{tabular}

a. Dependent Variable: Prestasi Belajar Y

b. Predictors: (Constant), Motivasi Belajar X2, E-learning X1

Sumber : Data diolah, 2020

Berdasarkan data tersebut dapat dilihat bahwa, nilai signifikasi untuk pengaruh media pembelajaran dan motivasi secara simultan terhadap prestasi belajar dengan tingkat signifikansi sebesar $<0,005$ dan nilai $F_{\text {hitung }} 91,388$

\section{Koefisien Determinasi $\left(\mathbf{R}^{2}\right)$}

\section{Koefisien Determinasi \\ Model Summary}

\begin{tabular}{|c|r|r|r|r|}
\hline Model & R & R Square & Adjusted R Square & $\begin{array}{c}\text { Std. Error of the } \\
\text { Estimate }\end{array}$ \\
\hline 1 &, $831^{\mathrm{a}}$ &, 690 &, 683 & 2,961 \\
\hline
\end{tabular}

a. Predictors: (Constant), Motivasi Belajar X2, E-learning X1

Sumber : Data diolah, 2020

Berdasarkan tabel 10 diatas, didapatkan milai Adjusted R Square (koefisien Determinasi) sebsar 0,683 yang artinya pengaruh variabel indepen (X) terhadap dependen (Y) sebesar 68,3\%. 


\section{Pembahasan \\ Pengaruh Media Pembelajaran (E-learning) Terhadap Prestasi Belajar Mahasiswa}

Hasil penelitian menunjukkan bahwa media pembelajaran (e-learning) mempunyai pengaruh positif terhadap prestasi belajar mahasiswa. Pada masa pandemi, mahasiswa yang semula belajar bertatap muka secara langsung dikelas dituntut untuk belajar menggunakan media pembelajaran secara online. Mereka berusaha mendapatkan cara penggunaan dan mengakses metode pembelajaran online. Pengetahuan baru pada pembelajaran online yang tidak didapatkan pada pembelajaran offline harus diikuti oleh mahasiswa. Materi perkuliahan tidak hanya mengandalkan penjelasan dari dosen saja tetapi mahasiswa dapat mencari dan mendapatkan pengetahuan baru yang tidak didapatkan sewaktu pembelajaran dikelas. Dengan keterbatasan tatap muka di kelas, mahasiswa dengan penuh kesadaran menggunakan berbagai media pembejaran (elearning) agar tidak ketinggalan materi sehingga hal ini menunjukkan dengan adanya media pembelajaran (elearning) mempunyai pengaruh positif terhadap prestasi belajar mahasiswa. Dengan demikian hipotesa pertama yang menyatakan dugaan pengaruh media pembelajaran (elearning) terhadap prestasi belajar dapat diterima. Penelitian yang sama dari penelitian Sri Tomo dan Bebas Widada (2016) yang menyatakan bahwa E-Learning berpengaruh positif terhadap Prestasi Belajar. Dukungan hasil penelitian tersebut membuktikan bahwa penggunaan media pembelajaran (elearning) yang dilakukan oleh pengajar di Universitas Semarang khususnya pengajar jurusan akuntansi untuk ditingkatkan agar minat belajar mahasiswa melalui media pembelajaran (elearning) berjalan lancar sehngga wawasan serta pengetahuan mahasiswa dapat bertambah.

\section{Pengaruh Motivasi Terhadap Prestasi Belajar Mahasiswa}

Hasil penelitian menyatakan bahwa motivasi mempunyai pengaruh yang positif terhadap prestasi belajar tetapi tidak signifikan. Motivasi mempunyai pengaruh dalam penentuan tingkat keberhasilan dalam berprestasi. Mahasiswa mempunyai keinginan mencapai hasil yang optimal dalam mengikuti perkuliahan yang diberikan pengajar dengan tujuan mendapatkan prestasi yang baik. Tugas yang diberikan pengajar baik tugas individu maupun kelompok akan dikerjakan dengan tujuan pencapaian prestasi berupa nilai. Untuk mencapai keinginan tersebut berbagai cara digunakan oleh mahasiswa, salah satunya tugas yang diberikan pengajar dikerjakan oleh orang lain atau hanya copy paste milik temannya. Hal inilah yang membedakan motivasi mahasiswa dalam mencapai prestasi yaitu pencapaian prestasi dengan meminta bantuan mahasiswa lain dan pencapaian prestasi dari usaha sendiri sehingga motivasi mempunyai pengaruh positif dan tidak signifikan terhadap prestasi belajar.

Hasil penelitian ini sesuai penelitian dari Ni Putu Trisna Windika Pratiwi (2019) yang menunjukkan bahwa motivasi belajar yang didapat oleh mahasiswa mempengaruhi prestasi belajar. mahasiswa yang giat atau mempunyai motivasi belajar akan menunjukkan kesetiaannya dengan terus mendorong dirinya sendiri untuk terus meningkatkan prestasi belajarnya. 


\section{Pengaruh Media Pembelajaran (E-learning) dan Motivasi Terhadap Prestasi Belajar Mahasiswa}

Hasil penelitian menunjukkan bahwa terdapat pengaruh variabel media pembelajaran (eleaning) dan motivasi belajar terhadap prestasi belajar. Hal ini dapat dilihat pada Uji F nilai $\mathrm{F}_{\text {hitung }} 91,388$ dan signifikan pada 0,000. Variabel media pembelajaran (elearning) dan motivasi belajar berpengaruh secara simultan terhadap Prestasi Belajar. Penelitian ini didukung oleh penelitian yang dilakukan oleh Haikal Firmansah Anas Pratama dan Sandy Arief, (2019) yang menyatakan bahwa E-learning dan Motivasi Belajar mempunyai pengaruh dengan tingkat signifikan $<5 \%$ terhadap Prestasi Belajar.

Media pembelajaran (e-learning) yang diberikan oleh Universitas Semarang khususnya fakultas ekonomi jurusan akuntansi sudah berjalan dengan baik dan Motivasi Belajar yang dilakukan oleh mahasiswa juga sudah berjalan dengan baik. Hal ini terlihat adanya jalinan komunikasi pembelajaran yang didapat oleh mahasiswa diluar jadwal perkuliahan online yang berdampak pada Prestasi Belajar.

\section{KESIMPULAN DAN SARAN}

Berdasarkan analisis data dan hasil pembahasan mengenai pengaruh media pembelajaran (elearning) dan motivasi terhadap prestasi belajar, kesimpulan dari hasil analisa sebagai berikut :

1. Hasil analisa pengujian menyatakan media pembelajaran (elearning) ada pengaruh positif dengan tingkat signifikan sebesar $<5 \%$ terhadap prestasi belajar mahasiswa S1 Akuntansi fakultas Ekonomi Universitas Semarang, artinya bahwa media pembelajaran (elearning) yang saat ini digunakan mempunyai pengaruh terhadap peningkatan wawasan dan pengetahuan mahasiswa sehingga meningkatkan prestasi mahasiswa.

2. Motivasi ada pengaruh yang positif terhadap prestasi belajar mahasiswa namun tidak signifikan, artinya motivasi yang dimiliki mahasiswa dalam mencapai prestasi berbeda-beda tergantung bagaimana mahasiswa tersebut dalam melaksanakan proses pembelajaran apakah pencapaian prestasi dari hasil kerja sendiri atau dibantu oleh mahasiswa lain.

3. Ada pengaruh positif antara media pembelajaran (elearning) dan motivasi belajar terhadap prestasi belajar mahasiswa, artinya jalinan komunikasi selama proses pembelajaran online antara pengajar dan mahasiswa berjalan dengan baik. Jalinan komunikasi ini terlihat adanya komunikasi diluar jadwal perkuliahan online sehingga berdampak pada Prestasi Belajar. 


\section{DAFTAR PUSTAKA}

Karwati, E. (2014). Pengaruh Pembelajaran Elektronik (e-Learning) Terhadap Mutu Belajar. Jurnal Penelitian Komunikasi Vol. 17 No. 1, 17(1), 41-54.

Rahmanisa, D. (2014, Januari 4). Tujuan, Manfaat \& Karakteristik E-learning. Diambil kembali dari Drahmanisa.blogspot.com: http://drahmanisa.blogspot.com/2014/01tujuan-manfaat-karakteristik-elearning.html?m=1

Manuhutu, S. (2015). Analisis Motivasi Belajar Internal Siswa Program Akselerasi Kelas VIII SMP Negeri 6 Ambon. Promosi Pendidikan Ekonomi, 3(1), 104-115.

Tomo, S., \& Widada, B. (2016). Pengaruh Pemanfaatan e-Learning terhadap Prestasi Belajar Mahasiswa. ilmiah sinusdan No. , 33-44.

Yadewani, D., \& Bayu, E. P. (2016). Pengaruh Pemanfaatan e-Learning dan Motivasi Bealajar terhadap Prestasi Belajar Mahasiswa. j-click Jurnal , 3(2), 2541-2469.

Emda, A. (2017). Kedudukan Motivasi Belajar Siswa Dalam Pembelajaran. Lantanida, 05(02), 93-196.

Rusmiati. (2017). Pengaruh Minat Belajar Terhadap Prestasi Belajar Bidang Studi Ekonomi Siswa MA AL FATTAH. UTILITY : Jurnal ilmiah pendidikan dan ekonomi, 1(01), 21-36.

Elyas, A. H. (2018). penggunaan model pembelajaran e-learning dalam meningkatkan kualitas pembelajaran. jurnal warta , 1-11.

Syafi'i, A., Marfiyanto, T., \& Rodiyah, S. K. (2018). Studi tentang Prestasi Belajar Siswa dalam Berbagai Aspek dan Faktor yang Mempengaruhi. Komunikasi Pendidikan, 2(2), 155-123.

Pratama, H. F., \& Arief, S. (2019). Pengaruh Pemanfataan e-Learning, Lingkungan Teman Sebaya dan Motivasi Belajar Terhadap Prestasi Belajar. Pendidikan Ilmu Pengetahuan Sosial, 6(1), 1-12.

Aurora, A., \& Effendi, H. (2019). Pengaruh Penggunaan Media Pembelajaran e-Learning Terhadap Motivasi Belajar Mahasiswa di Universitas Negeri Padang. JTEV, 05(02), 11-16.

Pratiwi, N. P. (2019). pengaruh motivasi belajar dan kecerdasan spiritual pada prestasi mahasiswa akuntasi. widya akuntasi, 1-14.

Taufiq, A. U., Kartina, \& H. D. (2019). Pengaruh Model Pembelajaran Awareness Training Terhadap Motivasi Belajar Fisika. Pendidikan Fisika , 7(1), 2355-5785 
